\title{
APLIKASI VERIFIKASI WAJAH UNTUK ABSENSI PADA PLATFORM ANDROID DENGAN MENGGUNAKAN ALGORITMA FISHERFACE
}

\author{
I Putu Putra Yana Wardana ${ }^{1}$, I A Dwi Giriantari ${ }^{2}$, Made Sudarma ${ }^{3}$
}

\begin{abstract}
The face is one part of the human body which are often used in biometric recognition system for high-level differences between the faces of the other faces. Android mobile application with additional security face recognition feature will add to the security of personal privacy of a person's use of telephone / mobile in particular that based on android. Extraction is one of the characteristics of the stages through which the development of biometric facial recognition systems on attendance face recognition applications. This stage aims to extract information from the face image so that it can be used as the unique features of the face in question. In this paper characteristics extraction step is done using face recognition algorithm Fisherface. The image of the face through the training process to the alignment faces and extraction fisherface which is then matched by comparing the value euclidiannya. The trial results in this study resulted in the algorithm fisherface not affect the change in facial expression, the distance, the use of additional attributes glasses hoods and lighting after testing showed generalization highest 100 percent in the test of the first, second and the lowest was 30 percent in testing the third
\end{abstract}

Keywords - Attendance, face recognition, mobile, android, fisherface

Intisari- Wajah merupakan salah satu bagian tubuh manusia yang sering digunakan dalam sistem pengenalan biometrik karena tingkat perbedaan yang tinggi antara wajah yang satu dengan wajah lainnya. Aplikasi mobile android dengan tambahan keamanan fitur pengenalan wajah akan menambah keamanan privasi seseorang penggunaan telpon pribadi/handphone khususnya yang berbasis android. Ektraksi ciri merupakan salah satu tahapan yang dilalui dalam pengembangan sistem pengenalan biometrik wajah pada aplikasi absensi face recognition. Tahap ini bertujuan untuk mengekstrak informasi dari citra wajah sehingga dapat digunakan sebagai ciri unik dari wajah bersangkutan. Pada paper ini tahap ekstraksi cirri face recognition dilakukan dengan menggunakan algoritma Fisherface. Citra wajah melalui proses pelatihan dengan penyelarasan wajah dan ekstraksi fisherface yang kemudian dicocokan dengan membandingkan nilai euclidiannya. Hasil uji coba pada penelitian ini menghasilkan algoritma fisherface tidak berpengaruh terhadap perubahan ekpresi wajah, jarak, penggunaan atribut tambahan kacamata kerudung dan pencahayaan setelah dilakukan pengujian didapatkan hasil

${ }^{1}$ Mahasiswa, Magister Teknik Elektro Fakultas Teknik Universitas Udayana, Gedung Pascasarjana Universitas Udayana Jl. PB Sudirman Denpasar 80232 INDONESIA (tlp/fax: 0361239599; e-mail:yana.s2wii@gmail.com

${ }^{2,3}$ Magister Teknik Elektro Fakultas Teknik Universitas Udayana, Gedung Pascasarjana Universitas Udayana Jl. PB Sudirman Denpasar 80232 INDONESIA (tlp/fax: 0361-239599; email: dayu.giriantari@yahoo.com

I Putu Putra Yana Wardana: aplikasi verifikasi wajah untuk .......... generalisasi tertinggi 100 persen pada pegujian pertama, kedua dan terendah sebesar 30 persen pada pengujian ketiga

Kata Kunci- Absensi, face recognition, mobile, android, fisherface

\section{Pendahuluan}

Verifikasi wajah merupakan proses pengenalan dan pencocokan wajah. Penggunaaan biometrika untuk sistem pengenalan mempunyai tujuan untuk meningkatkan kenyamanan dan keamanan manusia dalam lingkup privasi pribadi maupun dalam cangkupan lebih luas seperti untuk sebuah instansi, kelebihan biometrika punya banyak kemanfaatan dan keunggulan dibandingkan dengan sistem tradisional seperti: tandatangan manual, penggunaan password, PIN, kartu dan kunci yang sudah diaplikasikan pada: akses pintu masuk, absensi kehadiran, mesin ATM dan lainya.

Untuk sistem mobile biometrika masih sedikit dan bisa diekplorasi lebih beragam dan mendalam untuk dibahas. Aplikasi dengan tambahan keamanan seperti fitur pengenalan wajah akan menambah keamanan privasi seseorang penggunaan handphone khususnya yang berbasis android. Fitur pengenalan wajah ini didukung dengan perkembangan handphone yang sudah memiliki kemampuan kamera yang mumpuni dimuka dan dibelakang handphone. Harganya pun sudah semakin murah dari tahun ke tahun jadi semua orang dapat memilikinya dengan mudah seperti yang telah disampaikan diatas. Salah satu deteksi wajah yang penulis angkat adalah fisherface.

Algortima fisherface menurut Peter N Belhumeur yang sangat cocok digunakan/diimplementasikan di sistem aplikasi facerecognition yang berbasis android mobile. Berbasis android digunakan karena pesatnya perkembangan smartphone android dan sangat cocoknya algoritma penggabungan PCA dan FLD ini dengan kelebihan yang lebih ringan komputasinya namun performa dan waktu yang dibutuhkan lebih cepat dengan hasil klasifikasi yang lebih baik. Keunggulan lainnya dari fisherface (gabungan metode Principal Component Analysis dan metode Fisher's Linear Analysis) menghasilkan rasio vektor ciri yang besar (memperbesar rasio jarak antar kelas dengan jarak intra kelas dari vector ciri [4]) sehingga menghasilkan algoritma yang tidak sensitif walau terjadi perubahan arah cahaya, penambahan aksesoris dan perubahan ekspersi.

Penelitian tentang perangkat lunak berbasis android dengan verifikasi wajah telah banyak dilakukan. Salah satunya adalah penelitian oleh Donovan Gentles dalam tesisnya yang berjudul "Aplication of Biometrics in Mobile Voting". Tahun 2012, dalam penelitian tersebut memfokuskan tentang penggunaan aplikasi biometric untuk mobile voting [5]. Jurnal "Android 
Based Mobile Application Development and its Security", tahun 2012 oleh Suhas Holla, dkk, menuliskan hasil penelitian tentang keunggulan dan keamanan mobile application android based. Dalam penelitian Sin Kwan Kang tahun 2012 yang berjudul "A Study on the Mobile Communication Network with Smart Phone for Building of Location Based Real Time Reservation System" telah secara khusus menggunakan mobile based untuk sistem reservasi dengan menggabungkan augmented reality. Dalam penelitian tahun 2012 yang berjudul "Face Analysis and Recognition in Mobile Device"oleh Mauricio Villegas Santamaria telah secara khusus menggabungkan algoritma eigenfaces, algoritma fisherfaces dan algoritma local features untuk dapat menangkap wajah dan mengenalinya secara spesifik jenis kelamin dan namanya di perangkat mobile berbasis j2me khusus untuk seri N70. Artikel yang berjudul"Face Recognition Application on Android" oleh Aditya Pabbaraju dan Srujankumar Puchakayala, menggabungkan algoritma eigenfaces dan algoritma fisherfaces pada perangkat android mobile. Menghasilkan hasil kecepatan mendeteksi wajah 0,9 detik, preprocessing-nya 0,03 detik, projecting dengan eigen vector space 0,4 detik, detecting the min 0,01 detik (variable), similar growth entire process 1,4 detik. Jurnal tahun terbit 2012 atas nama Jianfeng Ren etc yang berjudul "A Complete and Fully Automated Face Verification System On Mobile Devices", pada artikel ini membahas verifikasi wajah di mobile khususnya untuk PDA dengan 02FN database

Berdasarkan penjelasan di atas dapat dilihat bahwa penelitian terhadap perangkat lunak berbasis android telah banyak dilakukan akan tetapi dari penelitian-penelitian tersebut, belum ada yang secara khusus mengembangkan aplikasi absensi berbasis android dengan algoritma fisherface untuk verifikasi wajah, dalam paper ini diujikan akurasi fisherface dalam parameter jarak, perubahan arah cahaya, sudut wajah dengan camera, ekspresi wajah dan penambahan acesoris seperti kacamata serta kerudung.

\section{FACE ReCOGNITION}

Salah satu dari pengembangan sistem keamanan yang berbasis biometrika yang sangat membantu menangkap dan meemecahkan masalah kejahatan karena dapat digunakan mengidentifikasi dan memverifikasi data penjahat karena menggunakan wajah sebagai pengenalan dan verifikasi dari sistem face recognition sehingga menghasilkan tingkat pengenalan dan verifikasi yang lebih baik daripada sistem keamanan manual [2].

Mendeteksi bagian citra wajah yang diperlukan sistem dalam proses face recognition adalah bagian vital/inti dari sistem pengenalan wajah tanpa terhalangi berbagai atribut pelengkap wajah [1] yang digunakan seperti penggunaan kacamata, kerudung, kumis dan jenggot. Sistem juga harus berhasil mendeteksi dengan berbagai variasi pose arah pencahayaan dan ekpresi wajah seseorang seperti citra wajah dalam keadaan cemberut, membuka mulut, tersenyum dan ekspresi wajah lainnya sistem harus tetap dapat mendeteksi wajah dan bukan wajah.

Daerah wajah dari dahi sampai dagu seperti juga rambut, dahi, alis, hidung, mata, pipi, gigi kulit dan dagu itu merupakan bagian dari wajah manusia. Ekspresi wajah, identitas diri dan penampilan itu ditunjukkan oleh wajah.
Semua itu harus berhasil diambil/di-capture oleh kamera. Bermacam iluminasi, pose dan ekpresi wajah YANG ditunjukkan saat pengambilan citra wajah harus berhasil diidentifikasi menggunakan citra dua dimensi dari wajah seseorang tersebut.

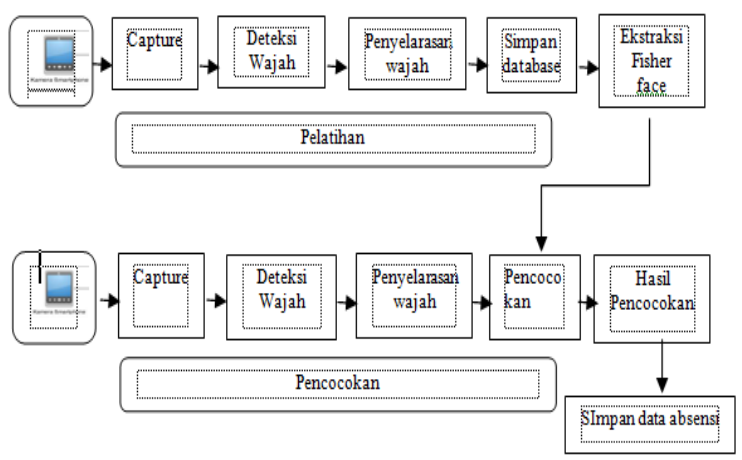

Gambar 1: Diagram Blok Deteksi Wajah Metode Fisherface

Algortima fisherface menurut Peter N Belhumeur yang sangat cocok digunakan/diimplementasikan di sistem aplikasi face recognition yang berbasis android mobile. Berbasis android digunakan karena pesatnya perkembangan smartphone android dan sangat cocoknya algoritma penggabungan PCA dan FLD ini dengan kelebihan yang lebih ringan komputasinya namun performa dan waktu yang dibutuhkan lebih cepat dengan hasil klasifikasi yang lebih baik. Keunggulan lainnya dari fisherface (gabungan metode Principal Component Analysis dan metode Fisher's Linear Analysis) menghasilkan rasio vektor ciri yang besar (memperbesar rasio jarak antar kelas dengan jarak intra kelas dari vector ciri [4]), sehingga menghasilkan algoritma yang tidak sensitif walau terjadi perubahan arah cahaya, penambahan aksesoris dan perubahan ekspersi, karena di mobile android dengan keterbatasannya dibandingkan dengan performa komputer jelas berbeda, sehingga penggunaan algoritma fisherface sangat membantu meringankan keterbatasan komputasi di mobile android.

Matriks input ini yang merupakan masukan untuk metode Fisherface.

\section{A. Penyelarasan Wajah}

Proses penyelarasan wajah sangat penting dalam proses face recognition karena merupakan proses yang bertujuan untuk mendapatkan citra wajah yang normal sama satu citra dengan citra lainnya / menormalisasi wajah dari citra wajah yang didapatkan dari proses pendeteksian wajah [6]. Banyak hal yang mempengaruhi kualitas citra wajah yang didapat/capture seperti faktor pencahayaan yang berbeda-beda kekurangan cahaya dan kelebihan cahaya ataupun faktor lainnya yang mempengaruhi kualitas citra menjadi buruk seperti ukuran yang lain dengan ukuran normal citra lainnya. Maka dari itu diperlukan proses menormalisasi (penyelarasan citra wajah). Dengan melakukan grayscaling (mengkonversi citra warna menjadi citra abu), dilanjutkan dengan proses pemotongan citra (didalam proses ini terjadi pemisahan citra wajah dengan latar belakang, jadi ada pengambilan citra wajah saja yang nantinya akan digunakan untuk proses pencocokan). Resizing (tahap normalisasi dimensi citra perlu dilakukan setelah proses pemotongan untuk mendapatkan ukuran citra yang diharapkan). Diakhiri dengan proses 
mengkoreksi tingkat kecerahan citra (Equalizing) mengakhiri proses penyelarasan wajah [2]

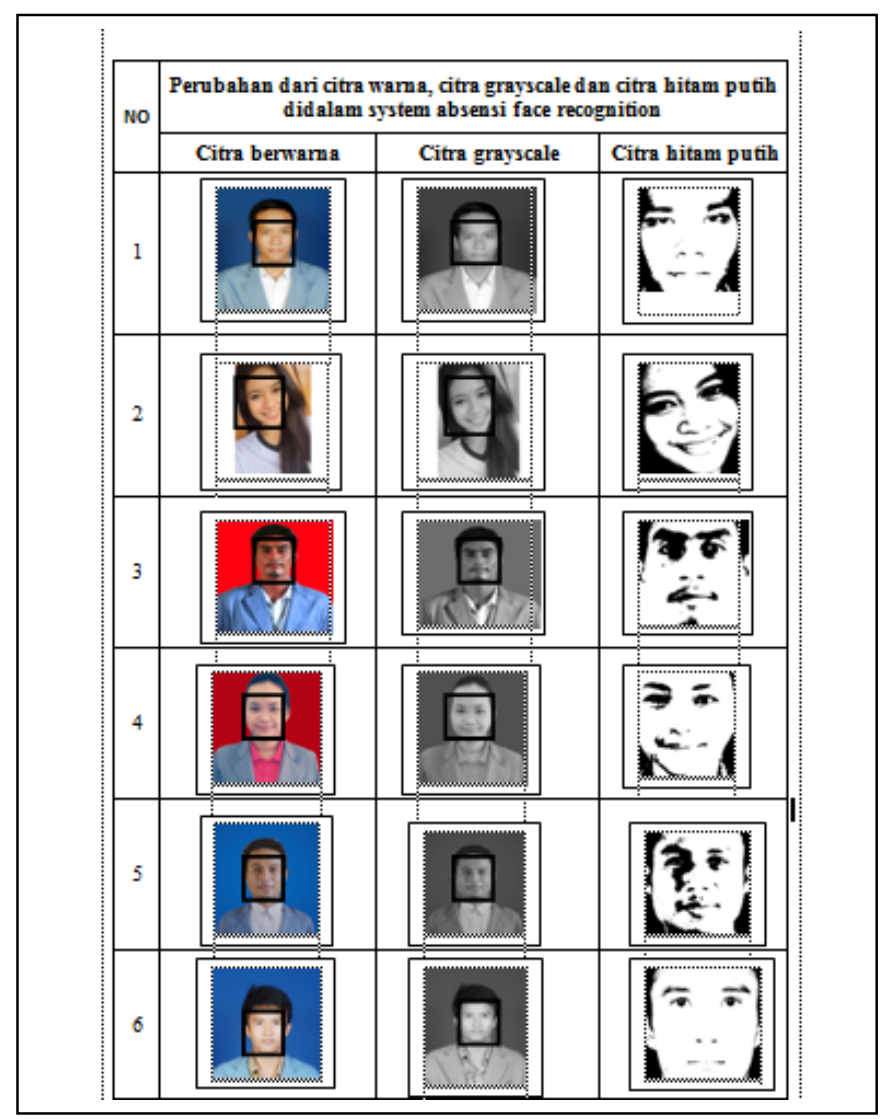

Gambar 2: Perubahan Citra Wajah didalam System Face Recognition

\section{B. Ekstraksi Fitur}

Simbolik (contohnya warna) dan numerik (contohnya intensitas) merupakan bagian dari fitur. Segala jenis aspek pembeda yang mempengaruhi kualitas ataupun karakteristik antara citra yang satu dengan citra wajah yang lainnya dinamakan fitur [12]

Mempercepat waktu komputansi dan memangkas penggunakan memori dibutuhkan dengan cara melakukan reduksi komponen. Melakukan reduksi komponen dapat dilakukan dengan cara pemilihan fitur fitur yang dianggap penting (feature selection) dan melakukan ekstraksi fitur itu sendiri (feature extraction) sehingga nantinya diharapkan dapat mengurangi waktu komputansi dan memangkas penggunaan memori. Pemilihan fitur bertujuan untuk memilih fitur fitur yang dianggap penting dan berperan dari fitur tersebut. Sedangkan memproyeksikan fitur kedalam dimensi yang lebih rendah dari sebelumnya disebut ekstraksi fitur. Hasil suatu algoritma ekstraksi terhadap citra wajah adalah fitur itu sendiri. Fitur masih mencerminkan karakteristik yang dimiliki oleh citra tersebut dan kadang fitur dari suatu citra tidak langsung berhubungan dengan bagian-bagian yang terdapat pada citra tersebut.

\section{Penyimpanan Fitur}

Citra wajah yg telah dilatih disimpan dengan ekstensi file berekstensi *xml. Proses penyimpanan fitur merupakan tahapan terakhir setelah melakukan pelatihan citra latih yang I Putu Putra Yana Wardana: aplikasi verifikasi wajah untuk . nantinya akan dibandingkan dengan citra uji. Proses ini berfungsi untuk menyimpan fitur hasil ekstraksi citra wajah yang ada di dalam database citra wajah. File inilah yang nantinya akan digunakan untuk proses pencocokan antara citra wajah yang diuji dengan hasil ekstraksi fitur yang terdapat pada file ini menghasilkan citra dikenali ataupun tidak dikenali [5].

\section{D. pencocokan}

Proses Pencocokan dilakukan dengan membandingkan citra latih dengan citra uji yg tersimpan di database citra wajah. Proses Pencocokan menghasilkan dikenali ataupun tidak dikenali seseorang dari proses face recognition. Dari Pencocokan fitur adalah tahapan inti dari pada proses pengenalan citra wajah. Proses ini merupakan proses pencocokan fitur dari citra uji dengan fitur citra wajah dari database, yang sebelumnya telah melalui proses pelatihan citra. Proses perbandingan ini dilakukan menggunakan metode pengenalan pola citra wajah yang telah dilatih tersimpan di database dengan citra uji yang ditangkap/capture oleh kamera, salah satunya adalah metode nearest neighbours [2].

\section{METODOLOGI}

Algortima fisherface menurut Peter N Belhumeur yang sangat cocok digunakan/diimplementasikan di sistem aplikasi face recognition yang berbasis android mobile. Berbasis android digunakan karena pesatnya perkembangan smartphone android dan sangat cocoknya algoritma penggabungan PCA dan FLD [4] ini dengan kelebihan yang lebih ringan komputasinya namun performa dan waktu yang dibutuhkan lebih cepat dengan hasil klasifikasi yang lebih baik. Keunggulan lainnya dari fisherface (gabungan metode Principal Component Analysis dan metode Fisher's Linear Analysis) menghasilkan rasio vektor ciri yang besar (memperbesar rasio jarak antar kelas dengan jarak intra kelas dari vektor ciri), sehingga menghasilkan algoritma yang tidak sensitif walau terjadi perubahan arah cahaya, penambahan aksesoris dan perubahan ekspersi.

Fisher's Linear Discriminant memilih matriks transformasi $W$ yang dapat memaksimalkan rasio antara determinan between-class scatter $\left(S_{B}\right)$ dengan within-class scatter $\left(S_{W}\right)$ dari vektor-vektor ciri melalui fungsi yang menjadi dasar dari algoritma Fisherface [4]:

$$
\begin{aligned}
\mathrm{W}_{\mathrm{opt}}= & \operatorname{argmax} \frac{\left|W S_{B} W^{T}\right|}{\left|W S_{W} W^{T}\right|} \\
& =\left[w_{1} ; w_{2} ; \ldots ; w_{m}\right]
\end{aligned}
$$

Dimana $[w 1 ; w 2 ; \ldots . ; w m]$ merupakan $m$ buah vektor eigen (dalam bentuk vektor baris) dari rasio antara $S B$ dengan $S W$, yang bersesuaian dengan $\mathrm{m}$ buah nilai eigen terbesar. Jika wi adalah vektor eigen dari rasio antara matriks $S B$ dengan matriks $S W$ dan di merupakan nilai eigen yang bersesuaian, maka:

$$
S_{B} W_{1}^{T}=d_{i} S_{w} W_{1}^{T}
$$


dimana $\mathrm{i}=1 \ldots \mathrm{m}$ dan $d 1>d 2>\ldots>d m$.

Jika $x i, \mathrm{i}=1 \ldots \mathrm{N}$ adalah vektor citra dimensi-n dan masing-masing vektor citra merupakan anggota salah satu dari $\mathrm{C}$ kelas citra wajah $\{X 1, X 2, \ldots, X C\}$ dan vektor u adalah ratarata vektor citra yang dapat diperoleh dari persamaan:

$$
\mu=\frac{1}{N} \sum_{i=1}^{N} X_{i}
$$

maka matriks $S B$ dan matrik $S W$ dapat diperoleh melalui persamaan berikut :

$$
\begin{aligned}
& S_{B}=\sum_{i=1}^{C} N_{i}\left(\mu_{i}-\mu\right)^{T}\left(\mu_{i}-\mu\right) \\
& S_{W}=\sum_{i=1 f=1}^{C} \sum_{i n_{j} e X_{i}}^{N_{i}}\left(x_{j}-\mu_{i}\right)^{T}\left(x_{j}-\mu\right)
\end{aligned}
$$

dimana, Ni adalah jumlah anggota kelas $X \mathrm{i}$ dan $\mu i$ adalah rata-rata citra anggota kelas $\mathrm{Xi}, \mathrm{i}=1$...C.

Suatu citra wajah dengan lebar dan tinggi masing-masing $l$ dan $t$ piksel mempunyai jumlah piksel sebanyak $l \times t$. Tiaptiap piksel dikodekan dengan nilai 0-255 sesuai dengan nilai tingkat keabuannya. Maka dapat dibentuk citra wajah berdasarka nilai keabuan tersebut yaitu:

$$
g_{i}=\left[\begin{array}{llll}
a_{11} & a_{12} & \ldots & a_{1 l} \\
a_{21} & a_{22} & \ldots & a_{2 l} \\
\ldots & \ldots & \ldots & \ldots \\
a_{t 1} & a_{t 2} & \cdots & a_{t l}
\end{array}\right]
$$

dimana $\mathrm{i}=1 \ldots \mathrm{N}$ (banyaknya citra wajah)

Setiap gi adalah anggota salah satu kelas wajah X. Jika terdapat $\mathrm{C}$ buah kelas wajah $\mathrm{X}$ maka terdapat $\mathrm{Xj}$, dimana $\mathrm{j}=$ 1..C. Untuk setiap kelas wajah $\mathrm{Xj}$ terdapat $\mathrm{Nj}$ citra wajah, dimana $\mathrm{j}=1$..C dan $\mathrm{N} 1=\mathrm{N} 2=\mathrm{Nj}$. Dengan demikian jumlah citra wajah adalah $\mathrm{N}_{1}+\mathrm{N}_{2}+\mathrm{N}_{3}+\ldots+\mathrm{N}_{\mathrm{c}}=\mathrm{N}$.

Dari vektor citra wajah di atas dapat dibentuk suatu vektor baris citra wajah yaitu: $x i=\left[\begin{array}{llll}a_{11} & a_{12} & \ldots & a_{g}\end{array}\right]$ $(1 * \mathrm{~N})$

Dengan demikian vektor citra dikatakan berada dalam ruang citra dimensi-n, dimana $i=1 \ldots$ N. Selanjutnya adalah membentuk matriks input berdimensi $\mathrm{N}^{*} \mathrm{n}$ yang berisi kumpulan vektor baris citra yang akan digunakan dalam pelatihan dan pengujian.

$$
\text { input }=\left[\begin{array}{c}
x_{1} \\
x_{2} \\
\ldots \\
x_{N}
\end{array}\right] \quad(\mathrm{N} * \mathrm{n})
$$

\begin{tabular}{|c|c|c|c|}
\hline & $\begin{array}{c}\text { Fisherface untuk } \\
\text { citra wajah dalam } \\
\text { kondisi memakai } \\
\text { kacamata }\end{array}$ & $\begin{array}{c}\text { normal dan } \\
\text { tanpa kacamata }\end{array}$ & $\begin{array}{c}\text { memakai } \\
\text { kacamata dan } \\
\text { tanpa } \\
\text { kacamata }\end{array}$ \\
\hline 2 & $\begin{array}{c}\text { Menguji } \\
\text { kemampuan } \\
\text { pengenalan wajah } \\
\text { dengan metode } \\
\text { Fisherface untuk } \\
\text { citra wajah } \\
\text { dengan variasi } \\
\text { ekspresi wajah }\end{array}$ & $\begin{array}{c}30 \text { citra } \\
\text { kelompok A, } \\
\text { sama dengan } \\
\text { training set } \\
\text { kasus I }\end{array}$ & $\begin{array}{c}30 \text { citra } \\
\text { kelompok A, } \\
\text { yaitu citra } \\
\text { wajah dalam } 5 \\
\text { ekspresi } \\
\text { wajah }\end{array}$ \\
\hline 3 & $\begin{array}{c}\text { Menguji } \\
\text { kemampuan } \\
\text { pengenalan wajah } \\
\text { dengan metode } \\
\text { Fisherface untuk } \\
\text { citra wajah } \\
\text { dengan variasi } \\
\text { posisi wajah } \\
\end{array}$ & $\begin{array}{c}30 \text { citra } \\
\text { kelompok B, } \\
\text { yaitu citra wajah } \\
\text { dalam } 4 \text { posisi } \\
\text { wajah }\end{array}$ & $\begin{array}{c}30 \text { citra } \\
\text { kelompok B } \\
\text { yaitu citra } \\
\text { wajah pada } \\
\text { berbagai } \\
\text { variasi posisi }\end{array}$ \\
\hline 4 & $\begin{array}{c}\text { Menguji } \\
\text { kemampuan } \\
\text { pengenalan wajah } \\
\text { dengan metode } \\
\text { Fisherface untuk } \\
\text { citra wajah } \\
\text { dengan variasi } \\
\text { arah cahaya } \\
\end{array}$ & $\begin{array}{c}30 \text { citra } \\
\text { kelompok C, } \\
\text { yaitu citra wajah } \\
\text { dalam memakai } \\
\text { jilbab dan tanpa } \\
\text { jilbab }\end{array}$ & $\begin{array}{c}30 \text { citra } \\
\text { kelompok C } \\
\text { yaitu citra } 4 \\
\text { variasi arah } \\
\text { cahaya }\end{array}$ \\
\hline 5 & $\begin{array}{c}\text { Menguji } \\
\text { kemampuan } \\
\text { pengenalan wajah } \\
\text { dengan metode } \\
\text { Fisherface untuk } \\
\text { citra wajah } \\
\text { dengan } \\
\text { penggunaan } \\
\text { atribut jilbab }\end{array}$ & $\begin{array}{c}30 \text { citra } \\
\text { kelompok C, } \\
\text { yaitu citra wajah } \\
\text { dalam memakai } \\
\text { jilbab dan tanpa } \\
\text { jilbab }\end{array}$ & $\begin{array}{c}30 \text { citra } \\
\text { kelompok C } \\
\text { yaitu citra } 4 \\
\text { variasi arah } \\
\text { cahaya }\end{array}$ \\
\hline
\end{tabular}

Tabel 1: Susunan Rancangan Percobaan

\begin{tabular}{|c|c|c|c|}
\hline Kasus & Tujuan & Training set & Test set \\
\hline \multirow{2}{*}{1} & $\begin{array}{c}\text { Menguji } \\
\text { kemampuan } \\
\text { pengenalan wajah } \\
\text { dengan metode }\end{array}$ & $\begin{array}{c}30 \text { citra } \\
\text { kelompok A, } \\
\text { yaitu citra wajah } \\
\text { dengan ekpresi }\end{array}$ & $\begin{array}{c}30 \text { citra } \\
\text { kelompok A, } \\
\text { yaitu citra } \\
\text { wajah }\end{array}$ \\
\hline
\end{tabular}

\section{HASIL DAN PEMBAHASAN}

A. Hasil

Penjabaran penjelasan awal sistem dari uji coba empat kasus diatas:

1. Perubahan pose tersenyum, membuka mulut, mengembungkan pipi, menyipitkan mata, menggunakan atribut tambahan seperti kacamata dan kerudung serta mengatur jarak pengambilan citra wajah dengan kamera tidak terlalu mempengaruhi akurasi pengenalan, yang terlihat pada persentase pengenalan wajah.

2. Pada pencahayaan yang normal prses pengenalan ternyata memberikan hasil yang lebih baik dibandingkan pencahayaan yang tidak konstan, ini disebabkan detail wajah yang lebih jelas, sehinggga kompleksitas warna wajah lebih tinggi pada pencahayaan yang tinggi.

Dapat diambil kesimpulan bahwa keberhasilan pengenalan dipengaruhi oleh beberapa hal, diantaranya:

1. Jarak anta kamera dengan seseorang

Untuk pengenalan yang baik, jarak antar seseorang dengan kamera saat pengambilan wajah dan proses deteksi sebaiknya jangan terlalu jauh karena menyulitkan kamera untuk melakukan proses deteksi wajah dan harus dibuat konstan jaraknya 
2. Pencahayaan lampu ataupun sinar

Pengenalan menjadi lebih sensitif dan menurunkan kualitas pengenalan jika pencahayaan yang terlalu tinggi mengakibatkan matriks dari gambar menjadi lebih kompleks serta membuat detail gambar yang lebih rumit,

3. Posisi Wajah.

Jika distorsi pose (miring ke kanan atau ke kiri) terlalu banyak sudut kemiringan akan menurunkan kualitas pengenalan dan untuk dapat mengenali pose wajah dari berbagai posisi tidak terlalu mempengaruhi hasil pengenalan.

Berikut antarmuka sistem, interface sistem ini berfungsi untuk mempermudah dalam pengoperasian aplikasi face Recognition yang dikembangkan. Aplikasi ini dibangun menggunakan bahasa pemrograman java pada android studio. Aplikasi "Absensi Face Recognition Fisherface" adalah antarmuka utama dari penelitian ini.

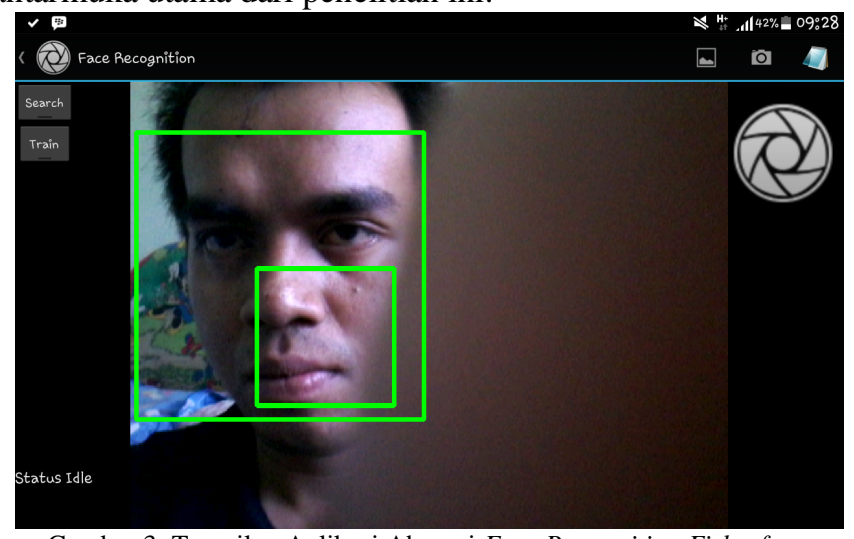

Gambar 3: Tampilan Aplikasi Absensi Face Recognition Fisherface

Untuk menjalankan program ini diawal pengguna (user) tinggal mengklik icon aplikasi face recognition dengan tujuan untuk melakukan proses absensi Face Recognition, pencocokkan database citra wajah dengan menggunakan algoritma yang digunakan terhadap citra uji. Berikut source code face recognition:

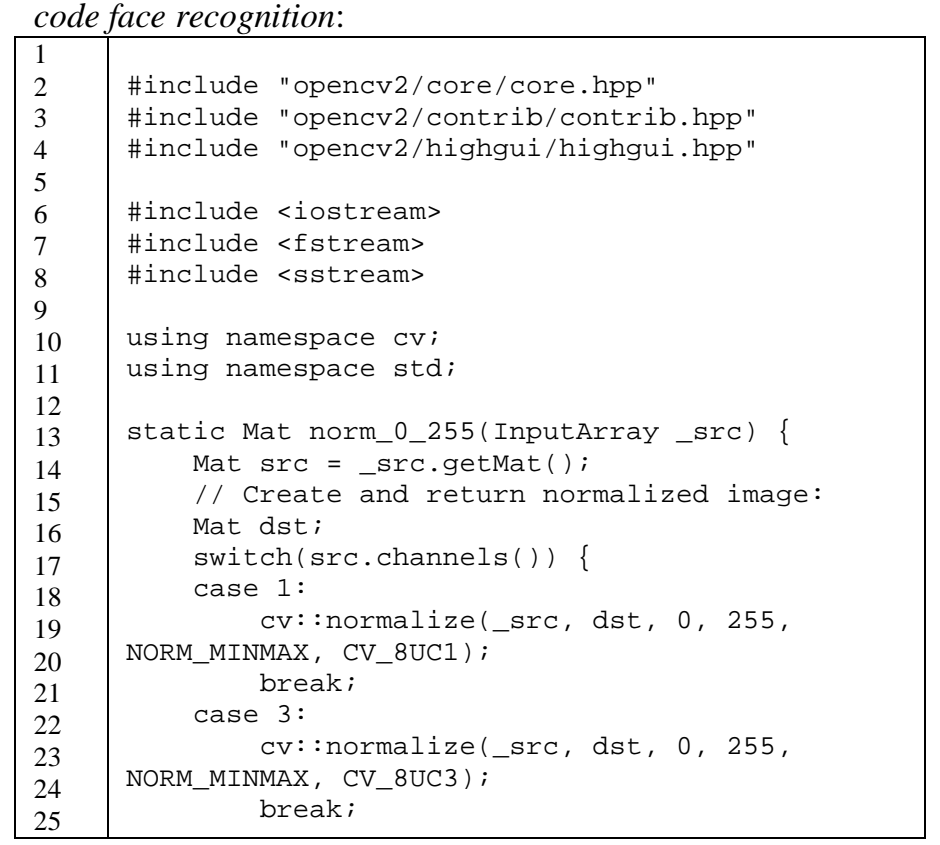

I Putu Putra Yana Wardana: aplikasi verifikasi wajah untuk ..........

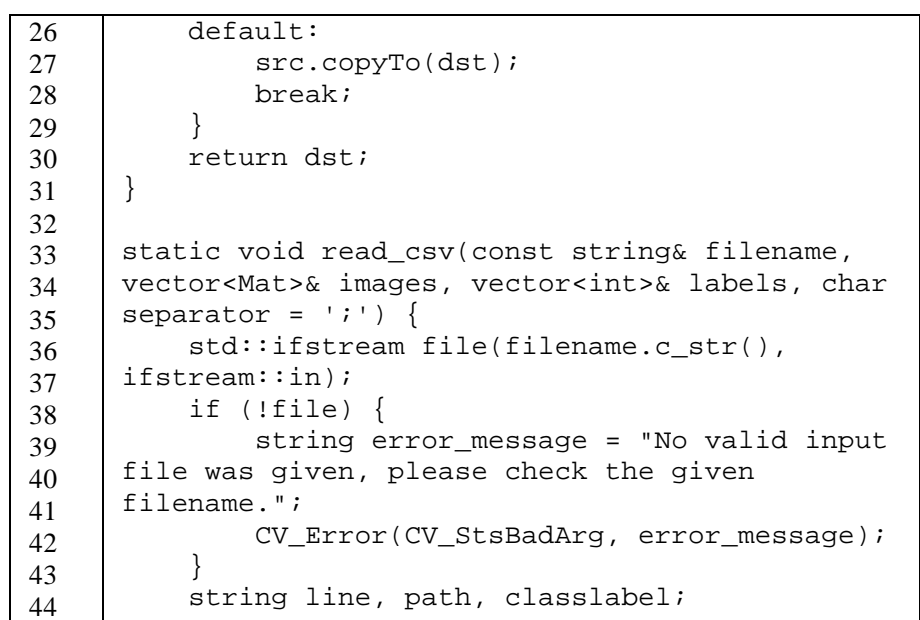

Sistem juga dapat menangkap citra wajah sampai tingkat kemiringan 15 derajat kemiringan wajah dari kamera tegak lurus dan tidak berpengaruh terhadap kurangnya pencahayaan dan ekpresi seseorang namun sistem tidak dapat mengenali citra wajah dari sebuah foto karena sistem tidak menangkap tekstur wajah yang akan dicocokkan dengan database citra wajah. Berikut gambaran sistem dapat menangkap citra wajah dengan tingkat kemiringan wajah 15 derajat.

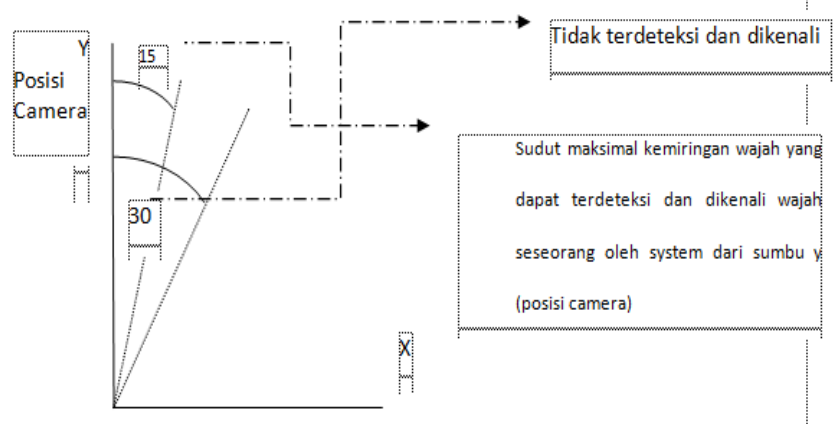

Gambar 4: Perkiraan Sudut batasan maksimal sistem

\section{B. Pembahasan}

Fokus utama penelitian ini adalah untuk mengetahui unjuk kerja sistem dalam hal ini akurasi pengenalan wajah. Oleh sebab itu parameter yang digunakan adalah parameter generalisasi. Generalisasi merupakan tingkat pengenalan yaitu kemampuan mengenali sejumlah pola yang diberikan. Dengan bantuan library OpenCV dan Java CV memudahkan penulis membangun sistem aplikasi face recognition dan menguji algoritma fisherface dalam mendeteksi wajah

Kasus I bertujuan menguji kemampuan sistem pengenalan dengan metode Fisherface untuk citra wajah dalam kondisi rentang jarak tertentu wajah ditangkap kamera untuk dicocokkan dengan database citra dan sudut wajah dari garis tegak lurus dengan kamera. Percobaan pertama pada kasus I ini menghasilkan vektor ciri berdimensi tiga dan didapatkan hasil generalisasi yang maksimal dari jarak 0,5 meter dan sudut wajah 5 derajat dari sudut tegak lurus wajah dengan kamera untuk hasil yang maksimal sistem dalam mengenali wajah sebesar 20/20 x 100\%, ini artinya keseluruhan citra wajah pengujian dapat dikenal, sedangkan pada sudut 15 derajat dalam jarak 0,5 meter sebesar $15 / 20$ x 100\% sebanyak 
75 persen tingkat akurasinya, lima citra wajah tidak berhasil dikenali oleh sistem. Dapat disimpulkan semakin jauh jarak pengambilan wajah dan semakin besar sudut kemiringan wajah dari tegak lurus wajah dengan camera, sistem semakin sulit mengenali bahkan tidak dapat mendeteksi dan mengenali wajah seseorang.

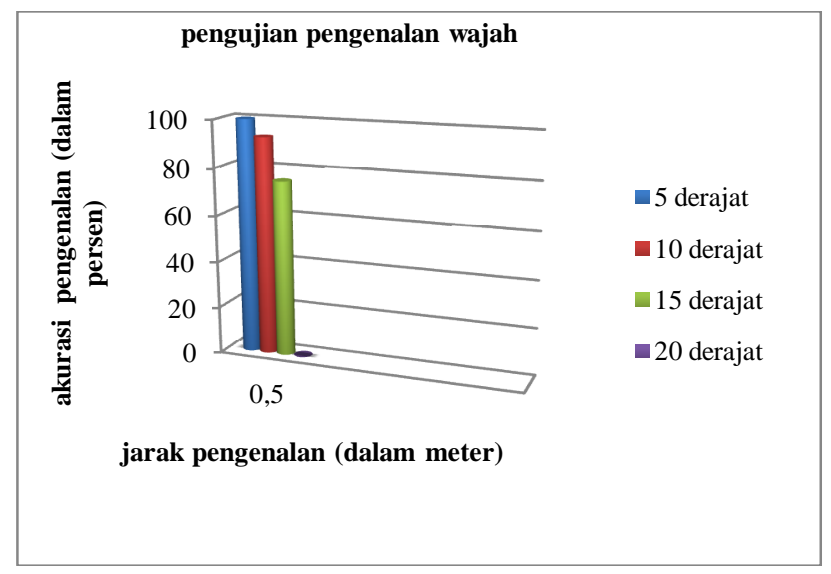

Gambar 5: Generalisasi Akurasi Pengenalan Wajah dengan Parameter Jarak dan Sudut Wajah

Kasus II bertujuan menguji kemampuan sistem pengenalan dengan metode Fisherface untuk citra wajah dalam kondisi rentang jarak tertentu wajah ditangkap kamera untuk dicocokkan dengan database citra dan penggunaan asesoris tambahan berupa kacamata. Percobaan pertama pada kasus II ini menghasilkan vektor ciri berdimensi tiga dan didapatkan hasil generalisasi yang maksimal dari jarak 0,5 meter menggunakan kacamata maupun tanpa kacamata untuk hasil yang maksimal sistem dalam mengenali wajah sebesar $20 / 20 \times 100 \%$, ini artinya keseluruhan citra wajah pengujian dapat dikenal sedangkan sebaliknya sistem tidak dapat mendeteksi maupun mengenali wajah pada jarak lebih dari 0,5 meter. Dapat disimpulkan semakin jauh jarak pengambilan wajah dan penggunaan kacamata menyulitkan sistem untuk mengenali wajah seseorang.

Kasus III bertujuan menguji kemampuan sistem pengenalan dengan metode Fisherface untuk citra wajah dalam kondisi arah pencahayaan dan penggunaan asesoris tambahan berupa jilbab untuk dicocokkan dengan database citra. Percobaan pertama pada kasus III ini menghasilkan vektor ciri berdimensi tiga dan didapatkan hasil generalisasi yang maksimal arah cahaya dari depan menggunakan jilbab maupun tanpa jilbab untuk hasil yang maksimal sistem dalam mengenali wajah sebesar $25 / 30$ x $100 \%$ yaitu delapan puluh tiga persen, ini artinya lima citra wajah berjilbab pencahayaan dari arah depan tidak dikenali dan hasil yang tidak jauh beda tanpa menggunakan jilbab dengan arah cahaya yang sama dari depan dengan nilai generalisasi sebesar delapan puluh persen, hanya enam citra wajah uji yang tidak berhasil dikenali. Hasil generalisasi sistem kurang maksimal dengan hasil 77 persen, tujuh citra wajah tidak dikenali dari total 30 citra wajah yang diujikan pada arah cahaya dari belakang dan dari kanan dengan memakai jilbab, hanya 23 citra wajah yang berhasil dikenali. Dapat disimpulkan perbedaan arah cahaya yang berubah drastis sangat berpengaruh terhadap sistem dalam mengenali citra wajah, jadi diharapkan citra training dengan citra wajah yang diuji memiliki kontras pencahayaan yang sama untuk memaksimalkan sistem dalam mengenali seperti kondisi pencahayaan gelap total sedikit cahaya dan kondisi pencahayaan terang baik di citra training maupun di citra uji

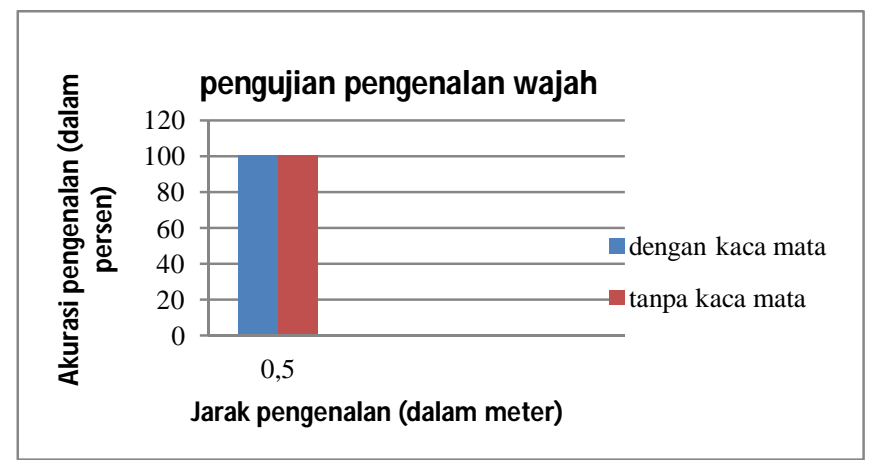

Gambar 6: Generalisasi Akurasi Pengenalan Wajah dengan Parameter Jarak Dan Kacamata

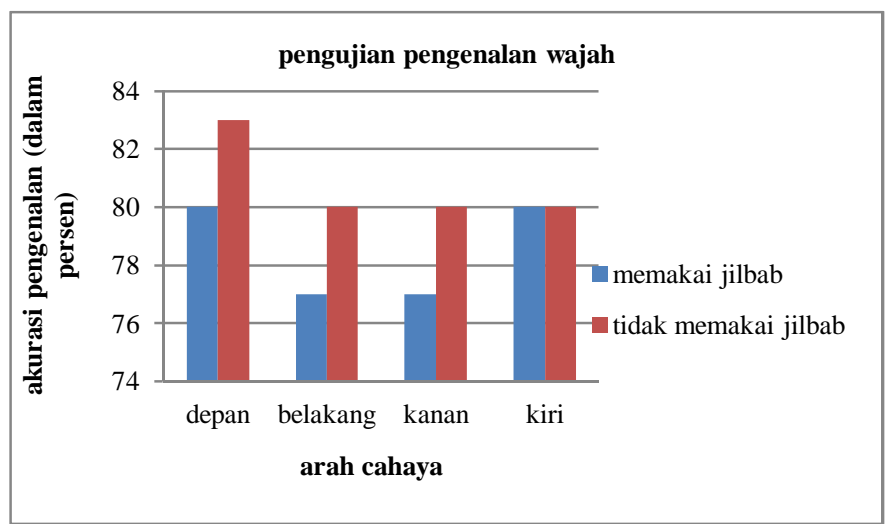

Gambar 7: Generalisasi Akurasi Pengenalan Wajah dengan Parameter Arah Cahaya dan Jilbab

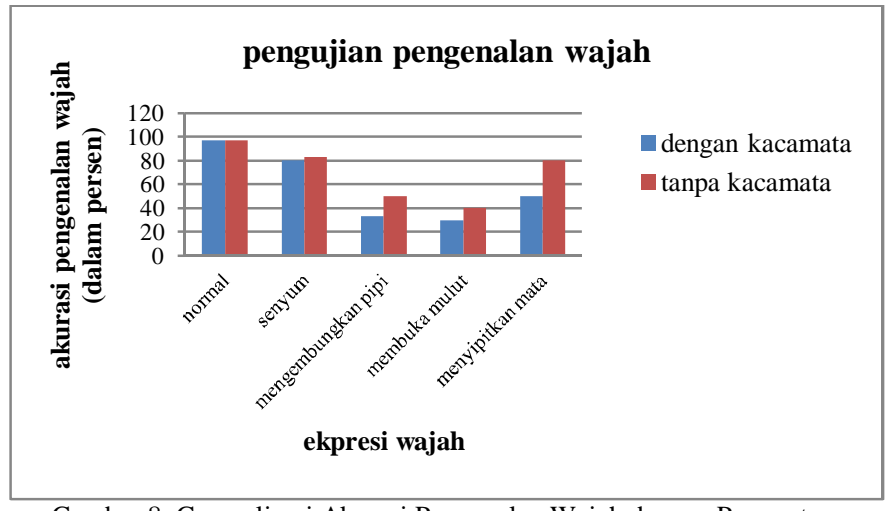

Gambar 8: Generalisasi Akurasi Pengenalan Wajah dengan Parameter Ekspresi Wajah dan Kacamata Tanpa Kacamata

Dapat disimpulkan semakin extreme ekspresi seseorang seperti mengembungkan pipi dan membuka mulut menyulitkan sistem untuk menangkap tekstur citra wajah seseorang ditambah penggunaan kacamata membuat sistem kurang maksimal dalam mengenali wajah seseorang

\section{KESIMPULAN}

Kesimpulan yang dapat diambil dan ditarik berdasarkan hasil pengujian sistem yang telah dilakukan dalam penelitian ini dengan menggunakan parameter generalisasi (dengan 
rumus jumlah pola dikenali dibagi seluruh pola dikali seratus persen) maka dapat disimpulkan :

1. Sistem absensi pengenalan wajah face recognition yang telah dikembangkan dengan algoritma fisherface tidak berpengaruh terhadap ekspresi wajah yang normal, pencahayaan yang normal dan penggunaan kaca mata setelah dilakukan uji coba sebanyak dua ratus tiga puluh database citra wajah. Ini sesuai dengan kelebihan dari fisherface memaksimalkan jarak antara gambar wajah yang kelas yang berbeda tetapi disisi lain meminimalkan jarak antara gambar wajah dari kelas yang sama

2. Hasil uji coba sistem ini menunjukkan bahwa sistem tidak dapat mengenali dan mencocokkan hasil tangkap kamera yang berupa citra wajah dari sebuah foto dengan database citra wajah yang tersimpan di database wajah yang telah di training

3. Sistem absensi pengenalan wajah face recognition mobile android hanya bisa menangkap citra wajah dengan kemirigan wajah kurang lebih lima belas derajat kemiringan dari tegak lurus camera dengan wajah

\section{REFERENSI}

[1] F. Agustina, "Implementasi dan Studi Perbandingan Metode Eigenface dan Fisherface dalam Metode Nearest Feature Line untuk Pengenalan Wajah 2 Dimensi," Skripsi, Universitas Indonesia, Jakarta, Indonesia, 2002 .

[2] F. Ardiyanto, "Sistem Pengenalan Wajah Berbasis Metoda Fisherface," Skripsi, Institut Teknologi Bandung, Jawa Barat, Indonesia, 2007

[3] B. Hermawan, Menguasai Java 2 \& Object Oriented Programming. Yogyakarta, Indonesia: Andi OFSET, 2004

[4] P. N. Belhumeur, P. H. Joã, and J. K. David, "Eigenfaces vs. Fisherfaces: Recognition Using Class Specific Linear Projection," IEEE Trans. Pattern Anal. Machine Intell, vol. 19, pp 711-720, 1997.

[5] Holla, Suhas. "Android Based Mobile Application Development and its Security," International Journal of Computer Trends and Technology, vol 3 Issue 3, 2012

[6] D. Putra, Pengolahan Citra Digital. Yogyakarta, Indonesia: ANDI Offset, 2010

[7] Rickyanto, Isak, Dasar Pemrograman Berorientasi Objek dengan Java 2 (JDK 1.4). Yogyakarta, Indonesia: ANDI Offset, 2005

[8] H. Safaat, Nazruddin, Android Pemrograman Aplikasi Mobile Smartphone Dan Tablet PC Berbasis Android. Bandung, Indonesia: INFORMATIKA BANDUNG Offset, 2011

[9] A. M. Turk, and P. P. Alex, (2014) Face Recognition Using Eigenfaces. [Online]. Available: http://www.cs.ucsb.edu/ mturk/Papers/mturkCVPR91.pdf

[10] W. Edi Dkk, Membuat Sendiri Aplikasi Android Untuk Pemula. Jakarta, Indonesia: Elexmedia Komputindo, 2011

[11] M. H Yang, D. J. Kriegman, and N. Ahuja, "Detecting Faces in Images: A Survey," IEEE Transcactions on Pattern Aanaly-sis and Machine Intelligence, vol. 24, no. 1, Jan. 2002.

[12] Mohsin, Waqar, Ahmed, Noman, Mar, Chung-tse, Face Detection Project, Department of Elec-trical Engineering, Stanford University. 2003. 
[Halaman ini sengaja dikosongkan] 